\title{
A Brief Analysis of the Application of Enterprise's Internal Accounting and Financial Management in Computer
}

\author{
Yulin Lan, Xuemei Li \\ Weifang Engineering Vocational College, Qingzhou, Shandong Province, 262500
}

\begin{abstract}
In the rapid development of the computer industry, the development of big data technology is getting faster and faster, and the requirements for data processing in corporate accounting and financial management are becoming more and more stringent. Therefore, the effective integration of computer data processing technology and corporate financial management is conducive to improving the overall efficiency of accounting work and improving the integrity of accounting information. Accounting informationization is the main development trend that must be faced in the process of financial management of Chinese enterprises. In the development of accounting informatization, we need to effectively apply computer technology and computer internal management procedures to realize the automation of financial work and intelligent operation and management. This will help improve the overall level of financial management and promote the healthy and stable development of my country's accounting industry. However, there are still some problems when we promote the application of accounting management on computers. In consequence, we need to study and analyze these problems and propose effective improvement measures. Only in this way can the corporate accounting management work be effectively combined with computer technology and the level of accounting informationization can be improved.
\end{abstract}

\section{Problems Existing in Computer Application in Enterprise Internal Accounting and Financial Management}

Accounting and finance have fully applied computer technology in the management process, and computer technology can promote the informatization development of accounting work. However, there are some problems in the process of accounting information development that will affect corporate accounting and financial management. First, there is no standard usage specification for accounting information software. The accounting staff in the financial department did not strictly follow the relevant operating specifications when operating the information software. Moreover, the degree of integration of software development is relatively low, and there are certain differences in the financial software workflow of different companies in the same industry. This will not only lead to relatively difficult use of accounting information software, but also large differences in data input and processing among different financial software. Second, the security of information software is relatively poor. The main manifestation is that there are hidden dangers in the accounting information software. For example, there are risks when installing pirated software. If there is an unexpected power failure, it may affect the statistical work of accounting information and cause the loss of accounting information data. External security risks mainly refer to computer virus intrusion and malicious attacks by hackers. Third, the compatibility of accounting software is relatively poor. At present, most accounting information software in our country is developed and designed by software companies. Because there are many software companies that develop accounting information, and there is no comprehensive internal communication development plan, there are certain differences in accounting information software used by enterprises, and they cannot obtain a unified data interface. Therefore, it is more difficult for accounting information software to share data on different systems. Fourth, the popularity of accounting information software is relatively low. Because accounting information software needs to invest a certain amount of capital and manpower in the application process, its penetration rate is relatively low. At this stage, my country's accounting information software industry has some problems in the development process, mainly due to the large differences in regional economies. The popularity of accounting information software in relatively developed coastal areas is relatively high, while the popularity of information software in inland areas and underdeveloped areas is relatively low. The main factor that affects the popularization of accounting information software is the professional quality of the staff. It is mainly manifested in the cognitive level of the managers and the actual operation ability of the staff. Third, there are internal control risks in the application of accounting software, 
and the scope of internal control of accounting information software is relatively large. The business connection between the accounting department and the corporate department is getting higher and higher, and traditional accounting work will affect the implementation effect of accounting information software to a certain extent. In addition to effective control of internal accounting information, enterprises must also prevent the adverse effects of competition between enterprises on accounting information software during the development of the industry. Therefore, we must pay attention to gradually promote the expansion of the scope of internal control of accounting informatization, summarize the financial information of each department, and make it input into the headquarters' accounting information system. This method may lead to the loss of the original vouchers of the department's accounting information, and affect the efficiency of accounting information file management [1].

\section{The Influence of Computer Application on Enterprise's Internal Accounting and Financial Management}

\subsection{Impact on Internal Audit}

In the internal control management of corporate accounting, internal auditing is its main component. Internal audit work can give full play to the supervision function of the corporate financial audit department and improve the overall efficiency and quality of accounting work. In traditional audit work, a separate audit department is mainly responsible for related work. The development of accounting informatization has affected the internal financial management and accounting work of enterprises to a certain extent. At this stage, companies can directly use computer information systems to complete analysis of various indicators and data. This can effectively improve the efficiency of the audit department and ensure the comprehensiveness of the audit content. For example, when conducting audit work, the audit department only needs to be responsible for the daily maintenance and management of the information system, check the software and hardware of the information system, and grasp the actual operation of the information system design program. In this way, the audit work can be completed and the overall quality of the audit work can be guaranteed. At the same time, we must also pay attention to the review and comparative analysis of the analysis, transmission, sharing, and storage of information data to ensure that the accounting computer information system can operate normally and stably, thereby improving the authenticity and accuracy of financial data.

\subsection{Impact on Internal Control}

When using computer information technology to carry out the internal accounting and financial management of enterprises, the key content of internal control will change to a certain extent. The use of accounting information technology to carry out financial management can not only save time and manpower input for internal control, but also help improve the efficiency and quality of accounting work in the financial department. When the original financial department carried out internal control work, we paid more attention to the management of staff. The use of accounting information software only needs to pay attention to the maintenance and control of the information system, which can improve the risk prevention level of enterprise control and financial management. The use of accounting information software can also use computers to check and compare the internal financial accounts of the enterprise to ensure the accuracy and completeness of the information data, which can greatly improve the quality of information data entry work.

\subsection{Impact on the Accounting Work Model}

The full application of computer technology in the process of corporate accounting and financial management is conducive to promoting the development of accounting information, which will have a certain impact on the traditional accounting work mode. These effects are mainly manifested in the following aspects. First, the content of traditional accounting work mainly includes generating information, accounting objectives, management, and transmission of information. The application of various information technologies will have a direct impact on traditional accounting work. In the process of information generation, traditional accounting completes information collection in manual form. The development of accounting informatization enables accountants to use computer information systems to complete the collection and preparation of accounting information, which can effectively improve the efficiency of accounting information collection and preparation. Second, in the process of applying accounting computer technology, accountants can realize paperless office. Using the advantages of network technology can not only increase the transmission speed of accounting information data, but also ensure that the sharing of accounting information can be completed in the shortest time. Third, the information data and accounting statements generated during the development of accounting informatization are clearer and clearer, which facilitates the effective application of financial accounting information by staff in other departments. This is conducive to meeting the requirements of the staff, improving the management level of enterprise managers, and providing accurate reference for enterprise decision-making. Finally, in the process of rapid development of information technology, traditional corporate accounting functions will gradually change. The financial department and staff will be more involved in the business management process. In addition, the status of corporate internal accounting and financial management in the process of corporate development is also constantly improving [2]. 


\section{Strategies to Promote the Application of Computer in Enterprise Accounting and Financial Management}

\subsection{Strengthen Talent Training}

To apply computer technology to corporate accounting and financial management, we need to pay attention to the training of talents. We must cultivate modern financial management personnel who are in line with the development needs of the enterprise, establish a systematic and comprehensive financial management concept, and carry out financial management personnel training based on this. Moreover, in the process of talent training, we must strengthen the communication and contact between various departments of the enterprise, and build an information-intelligent financial management work environment to provide a basic guarantee for the operation and development of the accounting information system, thereby improving the efficiency and quality of enterprise financial management. In the process of cultivating talents, we need to increase training in risk control according to the actual needs of the enterprise, so that financial managers can apply accounting information systems, thereby promoting the modern development of financial management. In addition, we must enable financial management staff to establish correct risk prevention awareness, improve staff awareness of risk management, and grasp the hidden risks of financial management in the process of enterprise development. At the same time, timely effective measures are taken to improve the application effect of the accounting information system [3].

\subsection{Pay Attention to Risk Management}

In the process of rapid development of computer technology, the development level of accounting information is getting higher and higher. In order to apply it in the process of corporate financial management, we need to pay attention to financial management and at the same time pay attention to financial risk management and control. When carrying out financial management, we must recognize the positive effects of the development of accounting information on the financial management of enterprises. Besides, we cannot ignore the adverse effects of the development of accounting information on the financial management of enterprises. We need to improve the risk prevention awareness and ability of financial management staff and establish a complete and comprehensive financial risk control system. We should make full use of the accounting information system to obtain corporate financial data and information, and enter the obtained data information into the accounting information system. Once we find abnormal information, we can find out the loopholes and failures in the accounting information work system in time, and take effective measures to compensate and maintain these loopholes to prevent the risk of financial information leakage or loss. In financial management, we should also pay attention to strict inspection and monitoring of the accounting information work system, and build a control system based on the security risks inherent in the accounting information work system. Otherwise, we also need to regularly inspect the software and hardware facilities of the accounting information system, and do a good job of inspection and supervision, so as to improve the standardization and standardization of corporate financial data and information management, and to ensure the security of financial information data.

\subsection{Carry out Internal Audit Work}

In the process of the development of accounting informationization, strengthening the internal auditing of corporate financial management is an important measure to improve the overall level of corporate financial management. Enterprises need to establish a strict and complete internal audit mechanism based on actual development. We must give full play to the supervisory role of internal audit work and improve the auditing level of the accounting information system. In the process of constructing the internal audit work mechanism, we need to ensure the integrity and effectiveness of the internal audit work system according to the actual situation of financial management [4]. We should improve the authority and independence of the internal audit work department so that the internal audit work department can be independent of the operation and management of other departments of the enterprise. This is also conducive to ensuring that we can comprehensively supervise and manage the internal business activities of the company when carrying out internal audit work. This is also conducive to timely detection of security risks in financial management, thereby improving the company's financial risk prevention capabilities. When enterprises apply accounting information systems, we must combine them with the internal audit work of the enterprise so that the internal audit work can be integrated into the enterprise accounting information system. We should give full play to the auditing function of the corporate financial management information system and improve the efficiency of internal auditing to ensure that the corporate financial management level is verified.

\subsection{Change the Concept of Financial Management}

Accounting informatization has greatly impacted the traditional financial management concepts, especially the rapid development of information technology has caused new changes in corporate accounting and financial management. In corporate financial management, we must establish advanced financial management concepts, adhere to people-oriented, establish scientific financial management concepts, attach importance to the training of financial management personnel, ensure that they are compatible with the development needs of the company, and improve the informatization of financial management personnel ability. In the process of updating the traditional financial management work concept, we must establish a more comprehensive and systematic 
financial management concept and attach importance to the informatization development of financial management work. Moreover, we also need the full application of computer technology to reflect the positive role of corporate accounting and financial management in computers. Furthermore, we must promote effective communication between various departments and organizational systems of the enterprise, and build a modern and informatized enterprise financial management system that conforms to the actual development of the enterprise, so as to improve the level of enterprise accounting information and ensure the efficiency of enterprise financial management[5] .

\section{Conclusion}

To sum up, in the process of rapid development of computer technology and information technology, promoting the application of corporate accounting and financial management in computers will help promote the further development of accounting information and improve the level of corporate financial management. In the process of promoting the development of accounting informatization, we need to recognize the impact of accounting informatization on corporate financial management. We are supposed to change the concept of financial management. Simultaneously, we must also pay attention to the importance of personnel training, internal control, and internal audit work, establish risk prevention awareness, and improve the risk prevention capabilities of corporate accounting and financial management. This will help ensure the overall quality of financial management and promote the healthy and long-term development of the enterprise.

\section{References:}

1. Zheng Pengfei. The application of accounting informationization to the internal financial management of enterprises [J]. Times Finance, 2018 (2): 239-239.

2. $\mathrm{Li}$ Zhenling. Analysis on the Application of Accounting and Financial Management in Enterprise Internal Control[J]. Science and Wealth, 2019, 000(024): 284.

3. Li Jianhong. Application of Computer Accounting System in Internal Control of Enterprise Accounting [J]. Financial Information (12): 52-52.

4. Cai Wenhua. Application of Computer Technology in Enterprise Financial Management[J]. Economic and Trade Practice, 2019, 000(012):175,177.

5. Li Zhuyin. Brief analysis of the application of financial management in the construction of enterprise internal control $[\mathrm{J}]$. Finance and Economics (Academic Edition), 2019, 000(020): 72-73. 